US Army Corps of Engineers ${ }_{\circledast}$

Engineer Research and

Development Center

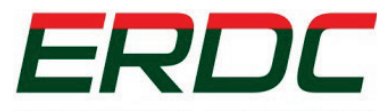

INNOVATIVE SOLUTIONS

for a safer, better world

\title{
Review and Evaluation of Reservoir Management Strategies for Harmful Algal Blooms
}

Brook D. Herman, Jed O. Eberly, Carina M. Jung,

July 2017

and Victor F. Medina

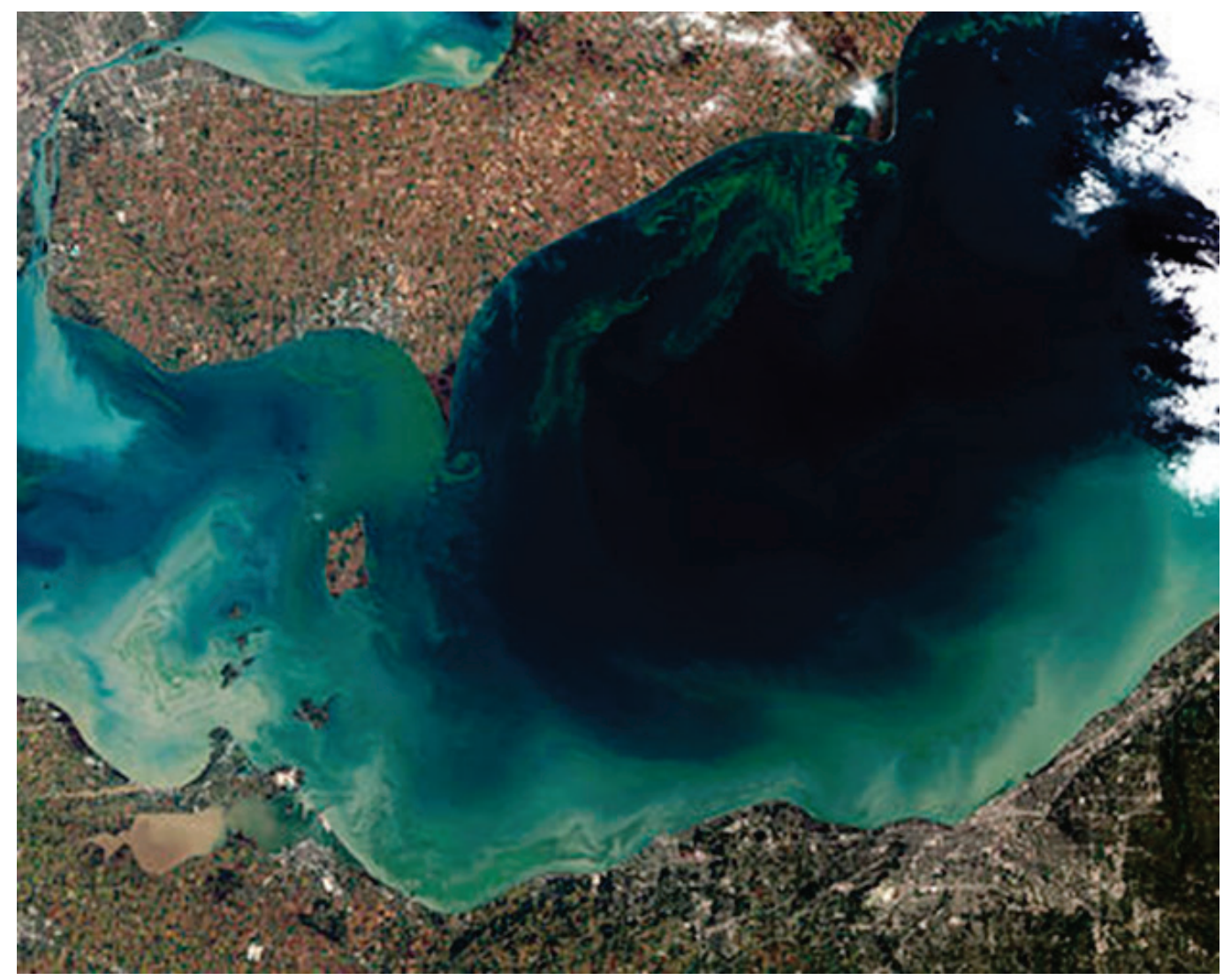


The U.S. Army Engineer Research and Development Center (ERDC) solves the nation's toughest engineering and environmental challenges. ERDC develops innovative solutions in civil and military engineering, geospatial sciences, water resources, and environmental sciences for the Army, the Department of Defense, civilian agencies, and our nation's public good. Find out more at www.erdc.usace.army.mil.

To search for other technical reports published by ERDC, visit the ERDC online library at http://acwc.sdp.sirsi.net/client/default. 
Review and Evaluation of Reservoir Management Strategies for Harmful Algal Blooms

Brook D. Herman, Jed O. Eberly, Carina M. Jung, and Victor F. Medina

Environmental Laboratory

U.S. Army Engineer Research and Development Center 3909 Halls Ferry Road

Vicksburg, MS 39180

Final report

Approved for public release; distribution is unlimited.

Prepared for U.S. Army Corps of Engineers

Washington, DC 20314-1000

Under Project Number WOTS-16-014, "Review and Evaluation of Reservoir Management Strategies for Harmful Algal Blooms" 


\section{Abstract}

The purpose of this report is to review and evaluate available information regarding reservoir operation strategies for management of harmful algal blooms (HABs). HABs can be problematic, creating eutrophication, and taste and odor issues. HABs also involve the release of toxins in the water column, which can cause sickness by ingestion and skin contact. This report presents the results of a review of journal articles, reports, published accounts of potential management options, effectiveness of management, and potential impacts of management actions on lake/reservoir ecosystem processes and biota, and recommendations for future research. This report concluded there is a range of methods that can be applied to address HABs in reservoirs. The efficacy of these methods decreases in larger reservoirs. No one method individually solves all problems or is applicable in all cases, a combination of methods will likely be needed. More research is needed to effectively control and prevent HABs.

DISCLAIMER: The contents of this report are not to be used for advertising, publication, or promotional purposes. Citation of trade names does not constitute an official endorsement or approval of the use of such commercial products. All product names and trademarks cited are the property of their respective owners. The findings of this report are not to be construed as an official Department of the Army position unless so designated by other authorized documents. 


\section{Contents}

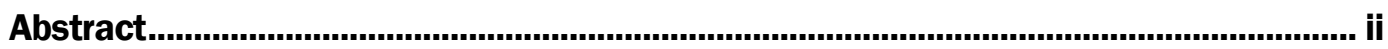

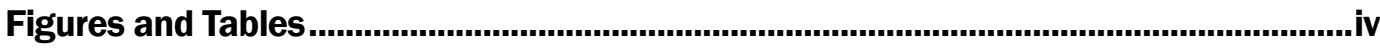

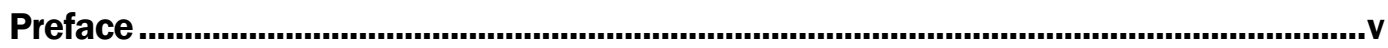





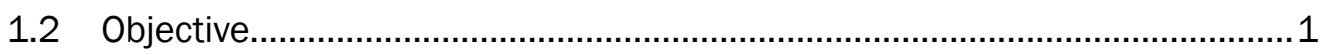

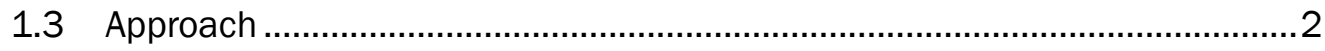

1.3.1 Conditions that Promote Harmful Algal Blooms in Lakes and Reservoirs............... 2

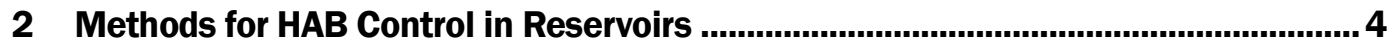

2.1 Water control management ................................................................ 4

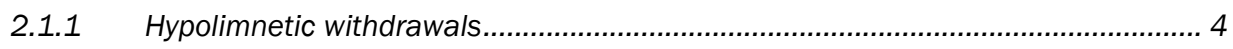

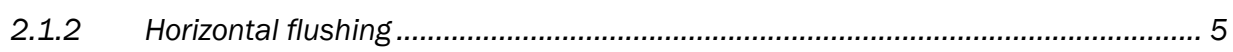

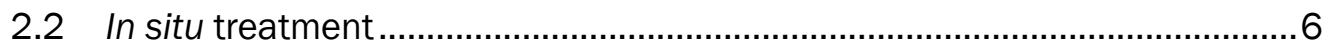



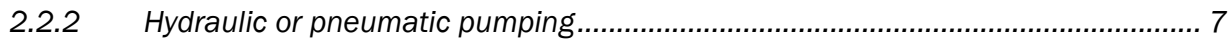



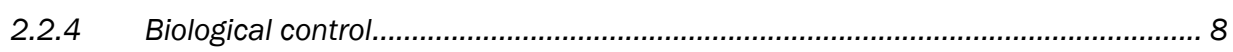

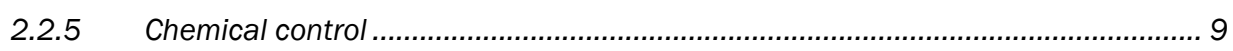

2.2.6 Physical disruption/Radical generation ........................................................ 10

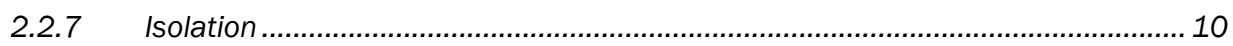

2.2.8 Nutrient removal/control ................................................................................... 11

2.3 Watershed management................................................................ 12

2.3.1 Nutrient/resource control.............................................................................. 12

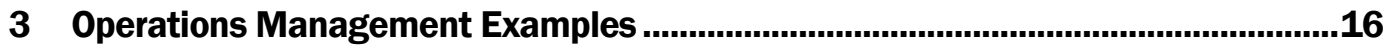

3.1 Purrysburg Reservoir, SC.....................................................................16

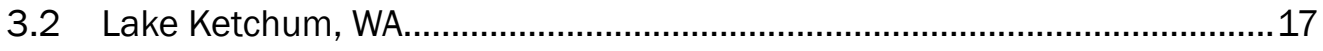

3.3 Jordan Lake, NC............................................................................. 17



\section{Concepts for Advanced Reservoir Treatment and Recommendations for}

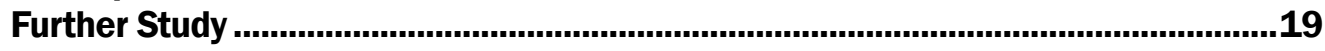





4.3 Conclusions from study .......................................................................

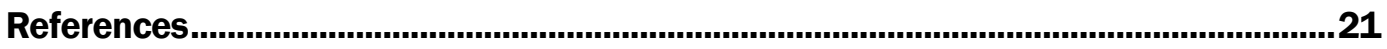

\section{Report Documentation Page}




\section{Figures and Tables}

\section{Figures}

Figure 1. Satellite image of Lake Erie in October 2011 during a record HAB event

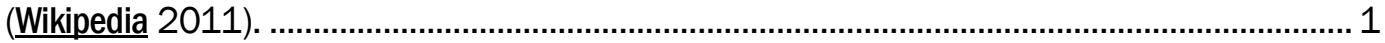

Figure 2. Wister Lake existing outflow stratification relationship (USACE 2008). ................ 5

Figure 3. Shade balls at the Los Angeles Reservoir............................................................. 8

\section{Tables}

Table 1. Summary of control methods for HABs in reservoirs..........................................13 


\section{Preface}

This study was conducted for the Water Operations Technical Support Program (WOTS) under Project number WOTS-16-014, "Review and Evaluation of Reservoir Management Strategies for Harmful Algal Blooms". The technical monitor was Patrick N. Deliman.

The work was performed by the Wetlands and Coastal Ecology Branch of the Ecosystem Evaluation and Engineering Division, and the Environmental Engineering and Environmental Processes Branches of the Environmental Processes and Engineering Division, U.S. Army Engineer Research and Development Center, Environmental Laboratory (ERDC-EL). At the time of publication, Patricia Tolley (CEERD-EEW) and Dr. William Martin were Chiefs (CEERD-EPE); Mark Farr (CEERD-EE) and Dr. Brandon Lafferty (CEERD-EPP) were Chiefs; and Dr. Patrick Deliman, CEERD-EV-E was the Technical Director for Water Operations Technical Support Program (WOTS). The Deputy Director of ERDC-EL was Dr. Jack Davis and the Director was Dr. Beth Fleming.

COL Bryan S. Green was the Commander of ERDC, and Dr. David W. Pittman was the Director. 


\section{Introduction}

\subsection{Background}

This report is in support of a request from the Louisville District, Water Quality Team, through the Water and Operations Technical Support (WOTS) program. The Louisville District manages twenty reservoirs within the Ohio River basin, and over half of their reservoirs experience HABs per year. HABs have increased in frequency of occurrence and intensity and occur in areas that have not experienced HABs before (Krientz et al. 2013, Michalak et al. 2013) (Figure 1). Currently, there is no published guidance or protocol for management of HABs with reservoir operations (e.g., timing of release of water). Additionally, questions remain about potential impacts associated with managing the water levels to control HABs on lake dynamics and biological assemblages.

Figure 1. Satellite image of Lake Erie in October 2011 during a record HAB event (Wikipedia 2011).

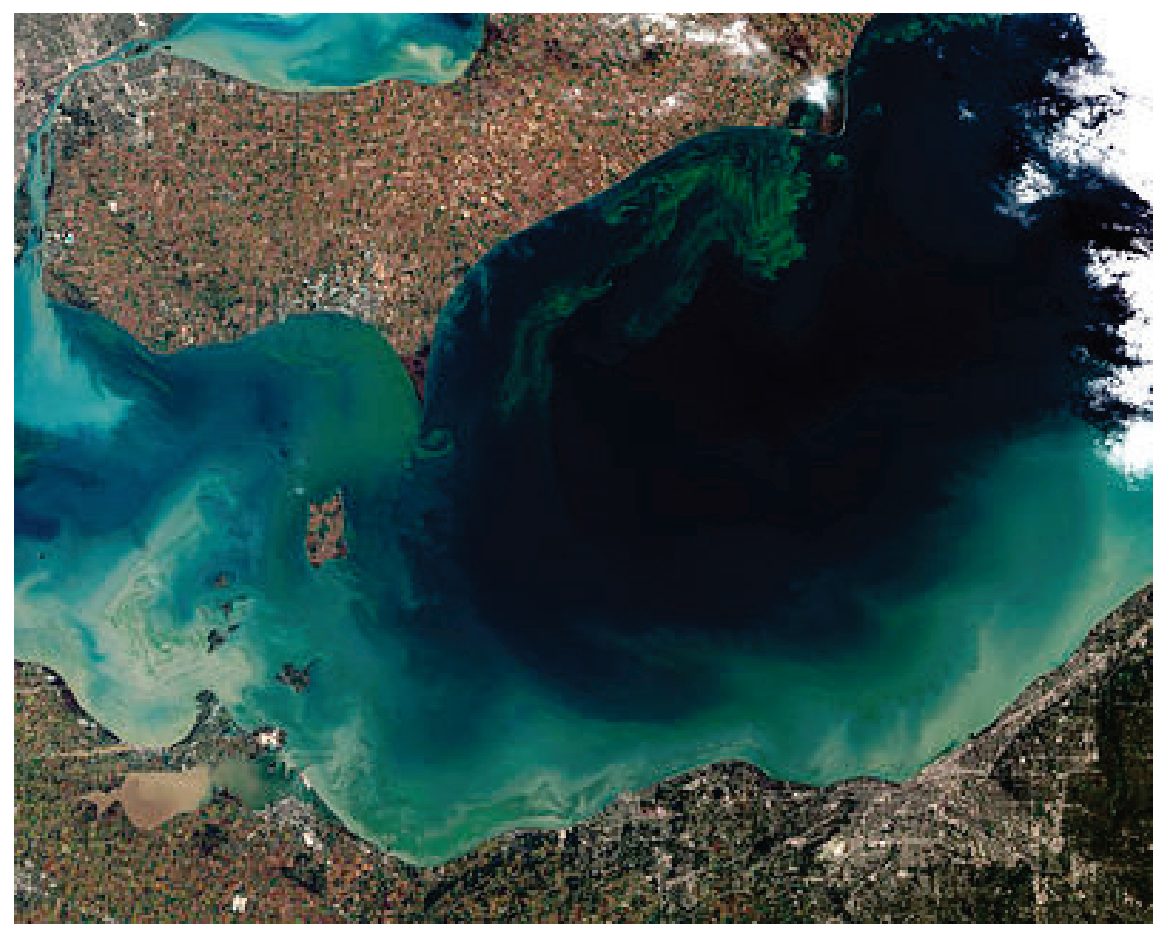

\subsection{Objective}

The purpose of this report is to review and evaluate available information regarding reservoir operation strategies for management of harmful algal 
blooms (HABs), which this report defines as including those caused by cyanobacteria. Algae blooms of any kind can be problematic, creating eutrophication and taste and odor issues. HABs, in particular, involve the release of toxins in the water column, which can cause sickness by ingestion and skin contact. This report presents the results of a review of journal articles, government reports, published accounts of potential management options, effectiveness of management, potential impacts of management actions on lake/reservoir ecosystem processes and biota, and recommendations of further research and study.

\subsection{Approach}

\subsubsection{Conditions that Promote Harmful Algal Blooms in Lakes and Reservoirs}

Understanding how HABs are formed is key to learning how to disrupt them. Numerous factors influence the formation and persistence of HABs, which may lead to hypoxia and toxin release (Mur et. al. 1999). The difficulty for lake and reservoir managers is understanding all the complex interactions between the physical, chemical, and biological conditions as well as the potential bloom forming organisms present in the water system. Such conditional factors include lake morphology, water-circulation patterns, light, nutrient concentration, temperature, grazing pressure from plant-eating fish, viruses, and microbial mechanisms (Patterson 2016, National Science and Technology Council 2016, and Kudela et al., 2015). Cultural (human caused) eutrophication leading to hypoxia often occurs in waters with a "susceptible physical structure." (National Science and Technology Council 2016) This is defined by a vertical density gradient, or stratification that separates well oxygenated surface water (e.g., epilimnion) from the sediment and bottom water (e.g., hypolimnion) and is driven by temperature, usually in summer months. Density stratification of the water column can encourage the growth of dinoflagellates or cyanobacteria, many of which can move vertically to optimize their access to light and nutrients, unlike true algae and plants. Since most HAB species colonize in the upper water level, they can shade and outcompete other non-toxic algal species that prefer deeper depths. Stratification also reduces the ability to replenish oxygen in deeper waters so that decomposition of organic material in bottom waters and sediments can further deplete any available oxygen. 
$\mathrm{HAB}$ species tend to be slow growing. As such, they generally require relatively long periods of exposure to good growth conditions. High concentrations of these species are commonly found in lakes, reservoirs, and ponds with long retention times. They are almost never found in flowing streams. However, once established, HAB causing organisms tend to be very effective competitors. Their uptake of nutrients is efficient, and they can survive in crowded conditions (Mur et al. 1999). In general, the slower the flow and the more sunlight and nutrients, the higher the likelihood of a bloom.

Although there has been significant improvements in the understanding of the biology of HABs, many questions remain unanswered, which creates uncertainties in trying to determine an appropriate management response to a $\mathrm{HAB}$ event. Although the obvious risk of no action will always be depletion of oxygen, the production of toxins is not a forgone conclusion. Not all algal species and strains of cyanobacteria produce toxins, and not all toxin-producers always create and/or release their toxins into surface waters (National Science and Technology Council 2016). Hence, the mere presence of algal blooms is not always indicative of risk to human and environmental health. Resource managers are challenged to consider detailed information such as algal growth patterns, environmental conditions, dominant species of algae, and the toxicological properties of relevant compounds from just the microbiological factors alone. Ultimately, management strategies need to be specifically tailored to the situation at hand and managers must be flexible in their approach, taking into consideration new information as it becomes known. The following is a review and evaluation of known and theoretical HAB management strategies. Table 1 (page 13) presents a summary of the following treatments reviewed. 


\section{Methods for HAB Control in Reservoirs}

\subsection{Water control management}

\subsubsection{Hypolimnetic withdrawals}

A hypolimnetic discharge is when there is a release of the cool, lower layer of water, which decreases the depth of the hypolimnion and creates shear forces that allow warmer surface water to reach lower depths and begin to mix with the cooler, lower layers. Hypolimnetic withdrawals also allow the potentially nutrient rich lower layer of water to leave the reservoir, thus removing a nutrient source that could become available to harmful algal organisms during a turnover event.

- Mixing is one way to decrease the temperature of the epilimnion (e.g., mix cool, lower layer with warmer, upper layer) and create less suitable conditions for the development and persistence of a HAB.

- Hypolemnetic withdrawals create localized mixing adjacent to the area of withdrawal and may not have a significant effect on a large body of water (Dortch 1997).

- Releasing nutrient rich water will only have an effect if the return water is low in nutrients (Burghdoff et al. 2012, and Paerl 2014).

- Localized mixing may increase turbidity that could possibly impact certain beneficial phytoplankton that species of invertebrates and fish may depend on; however, a small-scale experiment that looked at the effectiveness of mixing on Golden Algae reported no negative impacts to phytoplankton and zooplankton (Roelke et al. 2012).

- Nutrient rich waters may have an impact on downstream processes and biota. Water releases may need to be treated prior to release so that they are compliant with water quality laws and regulations.

- The United States Army Corps of Engineers (USACE) has used selective water withdrawal to manage reservoir water quality since 1973 (Schneider et al. 2004) (Figure 2). Success of this technique depends on having sufficient quantities of water available for release and proper elevation of outlet structures. Capital costs are quite high, but maintenance and operational costs are minimal (U.S. Army Corps of Engineers 2008).

- Loss or reduction of the cool layer may negatively impact cool water fisheries within a reservoir and/or reduce the ability to meet temperature targets downstream as well as within the tailwater. 
Figure 2. Wister Lake existing outflow stratification relationship (USACE 2008).

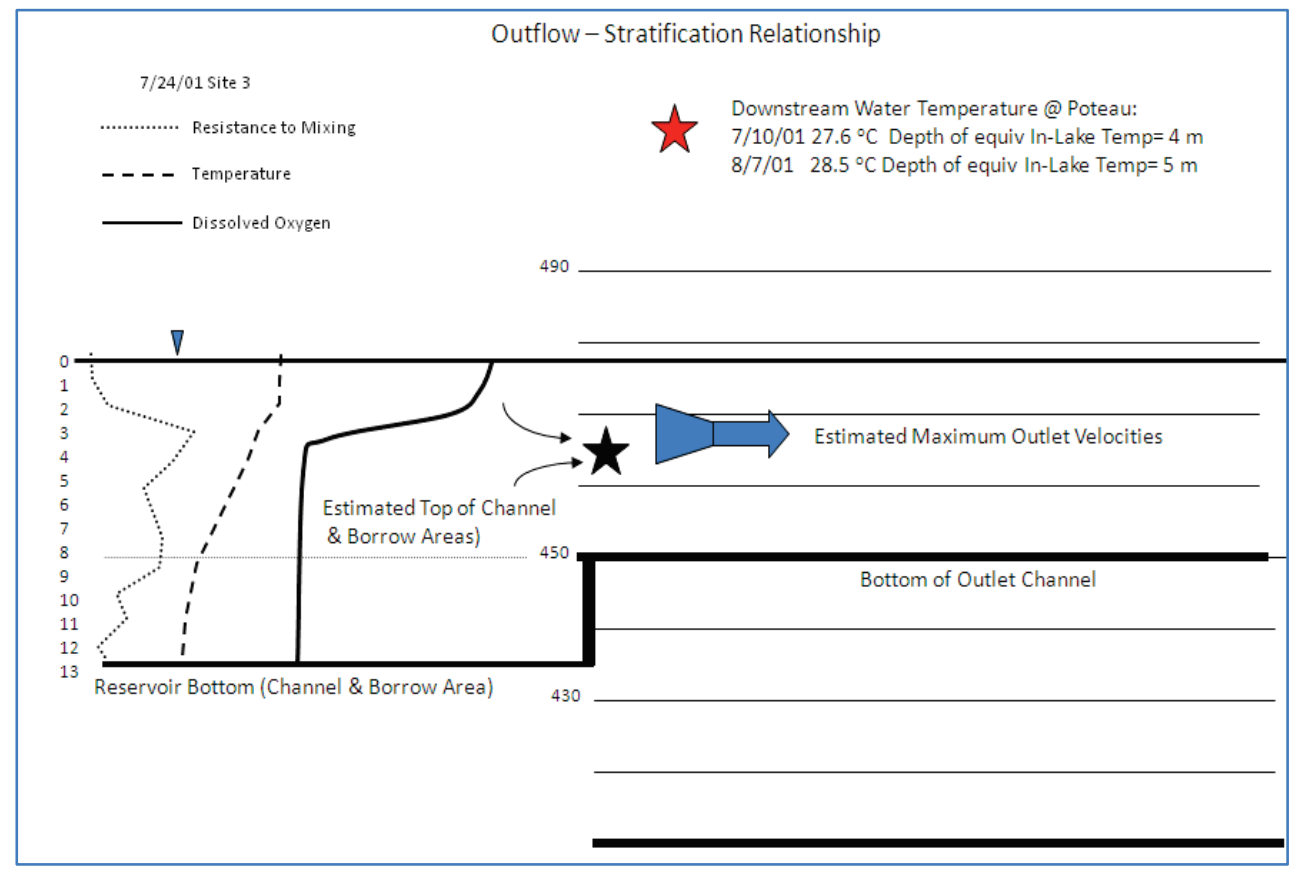

\subsubsection{Horizontal flushing}

Horizontal flushing is the release of the upper layer of water from a reservoir.

- Horizontal flushing decreases the residence time of the epilimnion and is thought to decrease the suitability of the waterbody for HABs, which benefit from long residence times (Paerl 2014).

- A limitation of this method is that the return water should be low in available nutrients (e.g., Phosphorus and Nitrogen) and be available at the appropriate time of year.

- Additionally, releases may be in conflict with recreation and navigation that require certain depths at certain times of the year.

- Large amounts of HABs transported downstream of reservoirs could potentially impact downstream biota. Graham et al. (2012) reported microcystin and taste/order compounds found 173 miles downstream of a reservoir after a horizontal flush were detectable from September to October. Although there was evidence of toxins downstream of release, there was no follow-up testing of fish or other aquatic species to see if toxins were accumulating or having a negative impact.

- It is unknown if this treatment would change the temperature of the upper water layer, which may depend on the size of the waterbody. A 
cooler, upper water layer may negatively impact certain species that depend on higher temperatures in the upper layer.

\subsection{In situ treatment}

\subsubsection{Mechanical mixing}

Mixing disrupts the control mechanism that many HAB causing organisms use to adjust their water column position and could be a very effective means of disrupting blooms or even preventing them. Mixing can be created by several means:

- Mechanical mixing is an established method and is commonly used to address algal growth in small ponds by use of machines specifically built to pump water from lower levels to the epilimnion.

- Applications to larger reservoirs are challenging, but possible, and have been described in several publications. For example, Cong et al. (2011) described the use of an aeration system that also provided mixing, which was tested on a drinking water supply reservoir in Tianjin, China. The system resulted in a 13\% reduction of chlorophyll agents.

- A concern with mixing is that it can be energy intensive (U.S. Army Corps of Engineers 2008), however, hydropower dams provide a ready power source. In addition, solar powered systems are currently commercially available. One example is the SolarBee system, a subsidiary of Medora Corporation (Dickenson, ND, http://www.medoraco.com/), which is solar powered and relatively easy to deploy. However, the application of SolarBees in Jordan Lake, North Carolina, was found to be ineffective, and their use was discontinued (North Carolina Department of Water Quality 2016).

- Potential impacts include boat recreation (which is driven by the number of mixers needed to address $\mathrm{HAB}$ problems), increases of available nutrients from lower water levels, and increases in turbidity. A smallscale experiment that looked at the effectiveness of mixing on Golden Algae reported no negative impacts to phytoplankton and zooplankton (Roelke et al. 2012). In some cases, mixing creates higher temperatures in the hypolimnion that are habitat-limiting to cool water species and could stimulate nutrient release from sediments (U.S. Army Corps of Engineers 2008). Mixing may induce artificial destratification. Turnover of stratified water bodies is a natural event, and artificial destratification may have negative impacts on native biota. Furthermore, artificial circulation may result in fouling of the structural components. 


\subsubsection{Hydraulic or pneumatic pumping}

Water or air can be pumped from the surface and injected at depth to promote mixing/destratification.

- Use of diffuser ports that create high-velocity water jets that carry warmer epilimnion water to the cooler hypolimnion can create mixing conditions that circulate algae below their optimal photic and temperature zone. This method can also create conditions that would prevent stratification of the water levels and decrease the probability of a turnover event (Dortch 1997). A turnover event would allow potentially nutrient rich water from lower levels to reach the upper water column favorable to $\mathrm{HAB}$ species.

- Little is known about the effectiveness of this strategy against HABs.

- Costs to operate and maintain pumps may be exorbitant.

- Turnover of stratified water bodies is a natural event, and artificial destratification may have negative impacts on native biota.

- Pumping of air or aeration is generally used to oxygenate the hypolimnetic zones of smaller lakes and may include the use of airlifts, hypolimnetic diffusers, downward flow oxygen contactors, and on-site oxygen generators. Aeration is most effective when the zone between the upper and lower layers remains oxygenated. If the zone between upper and lower layers remains oxygenated, sufficient iron is available to bind with available phosphorus, and oxidized iron precipitate is able to form. The precipitate is non-toxic to organisms.

- A disadvantage of aeration is the feasibility of implementation over a large area; therefore, smaller targeted treatment areas may yield positive results (U.S. Army Corps of Engineers 2008). Furthermore, there may be engineering or construction costs if underwater dam structures are required to retain cool water zones. Initial capital outlay may be inhibitory and there may be moderate yearly maintenance and operational costs (U.S. Army Corps of Engineers 2008).

\subsubsection{Floating Covers}

Sunlight can be blocked over the water's surface by floating artificial covers.

- Use of floating balls that cover open water has been used to decrease sunlight, decrease evaporation rates, and algal blooms. 
- The Los Angeles Department of Water and Power (LADWP) deployed floating covers over many of its drinking water reservoirs with the goal of reducing evaporation and limiting algal growth (Williams 2015). LADWP also explored the use of floating balls as a means of shading the water and found the approach to be effective. An application was made at the 176-acre Los Angeles Reservoir, the largest reservoir in the LADWP system (Figure 3).

- Limiting sunlight also has the advantage of limiting photochemical reactions that degrade water quality.

- Costs to maintain floating cover is not known in areas that experience winter ice cover.

- Impacts to ecosystem processes and biota have not been documented, but it is evident that decreasing sunlight will lead to decreased dissolved oxygen and, therefore, negatively impact biota.

- This would not be compatible with navigation and recreation. However, this may be feasible in areas that already have impacted recreation from a $\mathrm{HAB}$ as a temporary measure to control the HAB. The costs of temporarily installing and removing floating balls is unknown.

Figure 3. Shade balls at the Los Angeles Reservoir.

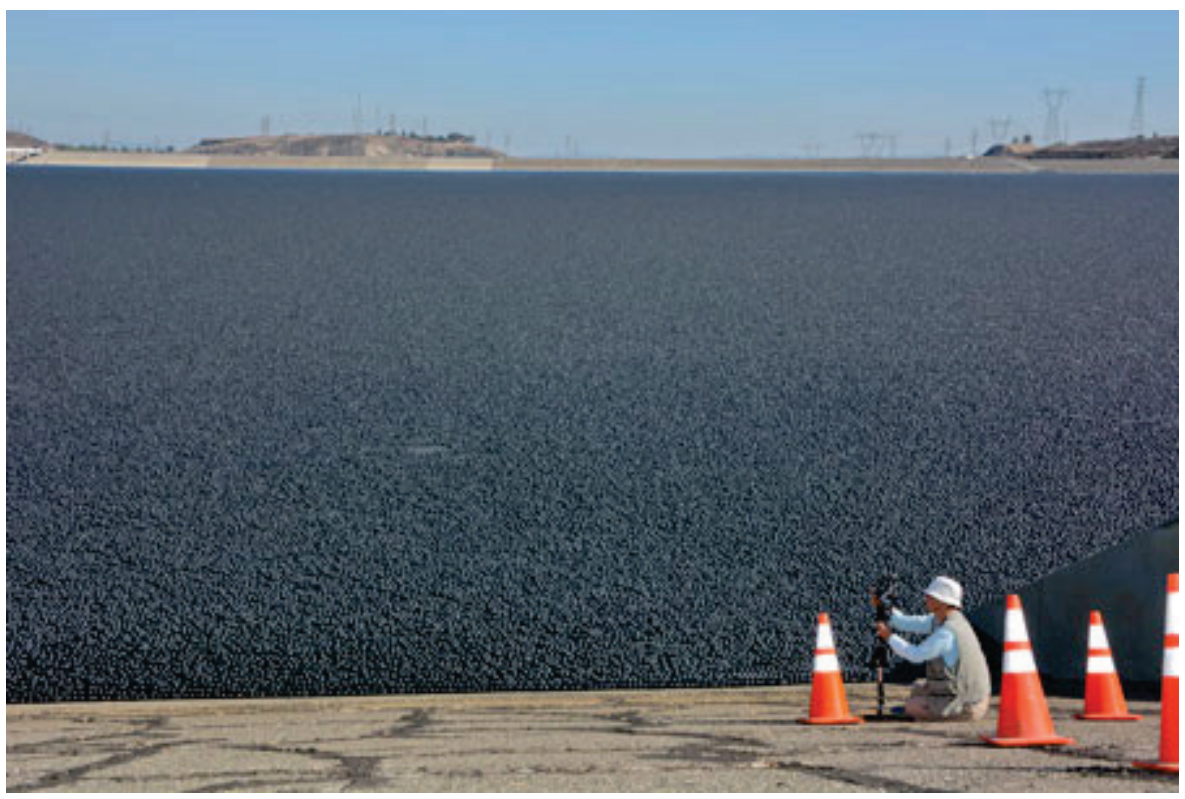

\subsubsection{Biological control}

Biological control takes advantage of biological processes to control HAB causing organisms. These include: 
- Predation. The use of predators/consumers to consume the harmful organisms. Filter feeding (e.g., planktivory) fish (e.g., Grass carp) are the most commonly used in North America. Some reports suggest that a high stocking rate may be needed to control HABs (Xie and Liu 2001). The use of zooplankton (e.g., protozoas, diatoms, etc.) to consume the organisms is encouraging, but are still in the experimental stage (Paul Oberholster, Research Biologist, Center for Scientific and Industrial Research, Pretoria, South Africa, Personal Communication). Although bacteria consume microcystins in the natural environment, which eventually mitigates their toxic effects (Mou et al. 2013), this process has not been intentionally tested as a treatment approach. Limitations of this approach are that the needed stocking rate would result in a depletion of desirable algae and would negatively impact native biota. In addition, Grass carp can escape areas of intentional release and become harmful in newly invaded areas.

- Competition. Macrophytes (e.g., submersed or floating plants) and relatively harmless algae can compete for nutrients and even sunlight. In many cases, these organisms can be very effective short-term competitors; however, $\mathrm{HAB}$ causing organisms are generally very effective long-term competitors.

\subsubsection{Chemical control}

Chemical control involves the use of algaecides, which kills HAB causing organisms.

- Copper sulfate $\left(\mathrm{CuSO}_{4}\right)$ is commonly used, but it also can negatively affect fish. Copper can build up in reservoir sediments (Fan et al. 2013), which result in short-term success in growth rebounds (Patterson 2016).

- Hydrogen peroxide is an attractive alternative because it can easily be applied, and it eventually breaks down into harmless byproducts (oxygen and water) (Barrington et al. 2013). Long-term impacts to biota are unknown.

- Chlorine was found to be very effective in a laboratory study (Fan et al. 2013).

- Chemical control is limited because the area of application is typically small. The cost of treating large areas may be prohibitive and detrimental to the environment. 
- A potential negative effect of treating HABs with algaecides is that the breakdown of HABs may release toxins stored in cell membranes and result in a massive toxin release (Paerl 2014).

\subsubsection{Physical disruption/Radical generation}

Physical disruption involves destruction of $\mathrm{HAB}$ causing organisms. These organisms that contain gas vesicles are particularly susceptible to violent physical disruption (Li et al. 2013, Li et al. 2015, Wu et al. 2012).

- Cavitation and ultrasonic disruption are proven methods for destroying many cyanobacteria and algae. Cavitation processes have often coupled with a secondary method to treat the toxins, such as ozone or superoxide radicals (Wu et al. 2012, Medina et al. 2016a). However, a strong cavitation field can produce radicals, like superoxide and hydroxyl radicals (research underway at USACE Engineer Research and Development Center (ERDC)). These radicals can effectively degrade microcystins (Shephard et al. 1998).

- Physical disruption/radical generation is best suited for water treatment systems and less suited for treatment of large waterbodies. For example, the KRIA water treatment system (also known under the trade name ECOSOAR) is a reactor that couples cavitation and radical production. It was tested in the laboratory and showed promising results (Medina et al. 2016a); however, it has not been demonstrated in the field. Additionally, physical disruption strong enough to lyse HAB causing organisms and to potentially generate radicals is likely created in a number of hydropower operations, including during releases from spillways, turbine operations, and fish pump operations.

- In some cases, and without the presence of free radicals, the broken cells can release contained toxins, resulting in a toxin spike.

\subsubsection{Isolation}

Isolation involves removing and containing the $\mathrm{HAB}$ causing species to limit their negative effects.

- Sheets can be used to isolate areas with HAB organism growth, or it might be possible to remove them from the water column by settling them out.

- Isolation may not be suitable for large HAB events.

- It may conflict with navigation and recreation. 
- Impacts to lake/reservoir processes and biota at large-scales are unknown.

\subsubsection{Nutrient removal/control}

Nutrient control generally involves limiting access to nitrogen $(\mathrm{N})$ and/or phosphorous (P). However, because nitrogen-fixing organisms can still provide a source of nutrients, phosphorous control is considered to be most effective. There is also some evidence to suggest that a measure of the ratio of total $\mathrm{N}$ to total $\mathrm{P}$ can inform the probability of a HAB depending on the type of waterbody (e.g., eutrophic vs. oligotrophic) (Chin 2015).

- Nutrient traps. The most common traps are the use of vegetated riparian zones, which are areas of dense foliage or wetlands that capture surface water flows and allow vegetation/bacterial processes to uptake and sequester nutrients prior to allowing surface water to discharge into lakes/reservoirs.

- Subsurface drains that support microbial activity that sequesters nutrients can be used.

- Algal scrubbers that use relatively safe algae can sequester nutrients, whereby water is pumped from the reservoir, run through algal mats (scrubbers), and then released back into the reservoir (Sindelar et al. 2015).

- Effectiveness of vegetated riparian zones and algal scrubbers is limited to the capacity of these controls to capture/treat surface water in relation to the amount of surface water entering the system.

- Dredged, nutrient rich sediment. The removal of nutrient rich sediment can remove a source of nutrients that can be seasonally available to HAB causing organisms (e.g., fall turnover). However, dredging can be cost prohibitive, finding appropriate areas for placement can be problematic, and impacts of dredging on aquatic organisms can be significant requiring mitigation. Additionally, dredging would be inappropriate for areas still receiving nutrient rich inputs.

- Clay or Aluminum or Iron coagulants. Dispersement of particles will bind nutrients (e.g., phosphorus) and settle out of the water column. Treatment with coagulants were found to be effective in small areas (Kim 2012). Long-term impacts to bottom dwelling benthos and length of time nutrients remain sequestered are unknown. Treatment with coagulants may not be suitable for large waterbodies. Other issues with nutrient inactivation are that it can lower $\mathrm{pH}$ and be toxic if coagulants 
are added in excessive concentrations (U.S. Army Corps of Engineers 2008).

\subsection{Watershed management}

\subsubsection{Nutrient/resource control}

Nutrient control generally involves limiting access to nitrogen and/or phosphorous. However, because nitrogen-fixing organisms can still provide a source of nutrients, phosphorous control is considered to be most effective. Nutrient input control is generally accomplished by:

- Limiting discharges of nutrients in surface water entering system. Nutrient management of surface water input is potentially the most effective means of dealing with HABs.

- Implementing nutrient control within the watershed is very challenging because the highest source of nutrient sources is most commonly found in non-point sources, particularly from agriculture. Scavia et al. (2016) showed that nutrient control could be effective at limiting algal blooms in Lake Erie, but only certain strategies were effective.

- USACE has no authority to control these kinds of sources; however, USACE could partner with public agencies to conduct ecosystem restoration of areas within a watershed that may have incidental benefits, such as nutrient reduction. 
Table 1. Summary of control methods for HABs in reservoirs.

\begin{tabular}{|c|c|c|c|c|}
\hline $\begin{array}{l}\text { General Control } \\
\text { Approach }\end{array}$ & Method & Description & Reference & Comments \\
\hline \multirow[t]{2}{*}{$\begin{array}{l}\text { Water Control } \\
\text { Management }\end{array}$} & $\begin{array}{l}\text { Hypolimnetic } \\
\text { withdrawal }\end{array}$ & $\begin{array}{l}\text { Remove water } \\
\text { from lower layer }\end{array}$ & $\begin{array}{l}\text { Burghdoff, } \\
2012\end{array}$ & $\begin{array}{l}\text { Effects may be } \\
\text { localized; may be } \\
\text { counterproductive } \\
\text { if nutrients mixed } \\
\text { with upper layer, } \\
\text { may have } \\
\text { downstream } \\
\text { impacts. }\end{array}$ \\
\hline & $\begin{array}{l}\text { Horizontal } \\
\text { flushing }\end{array}$ & $\begin{array}{l}\text { Release upper } \\
\text { zone of water } \\
\text { from reservoir to } \\
\text { flush HAB } \\
\text { downstream. } \\
\text { Allow lower layers } \\
\text { to move up and } \\
\text { create mixing. }\end{array}$ & Paerl 2014 & $\begin{array}{l}\text { May not be } \\
\text { practical in } \\
\text { drought } \\
\text { situations; may be } \\
\text { in conflict with } \\
\text { navigation and } \\
\text { recreation; and } \\
\text { has potential } \\
\text { downstream } \\
\text { impacts. }\end{array}$ \\
\hline \multirow[t]{4}{*}{$\begin{array}{l}\text { In situ } \\
\text { Treatment }\end{array}$} & $\begin{array}{l}\text { Mechanical } \\
\text { Mixing }\end{array}$ & $\begin{array}{l}\text { Pumps to } \\
\text { circulate water }\end{array}$ & $\begin{array}{l}\text { Granquist } \\
2010\end{array}$ & $\begin{array}{l}\text { Energy costs can } \\
\text { be a factor; may } \\
\text { not be effective in } \\
\text { large waterbodies. }\end{array}$ \\
\hline & $\begin{array}{l}\text { Hydraulic/pneu } \\
\text { matic pumping }\end{array}$ & $\begin{array}{l}\text { Pump air or } \\
\text { surface water to } \\
\text { lower layer of } \\
\text { water }\end{array}$ & $\begin{array}{l}\text { Dortch } \\
1997\end{array}$ & $\begin{array}{l}\text { May release } \\
\text { nutrients stored in } \\
\text { lower layer; } \\
\text { unknown } \\
\text { effectiveness in } \\
\text { large waterbodies. }\end{array}$ \\
\hline & Floating Cover & $\begin{array}{l}\text { Block sunlight w/ } \\
\text { artificial covers: } \\
\text { balls or other } \\
\text { floating covers }\end{array}$ & $\begin{array}{l}\text { Williams } \\
2015\end{array}$ & $\begin{array}{l}\text { Unknown } \\
\text { effectiveness in } \\
\text { large waterbodies; } \\
\text { uncertain impact } \\
\text { to desirable biota; } \\
\text { conflict with } \\
\text { navigation and } \\
\text { recreation. }\end{array}$ \\
\hline & $\begin{array}{l}\text { Bio-Control: } \\
\text { Grass carp and } \\
\text { other fish }\end{array}$ & Consume algae & $\begin{array}{l}\text { Granquist } \\
2010\end{array}$ & $\begin{array}{l}\text { Limited to low } \\
\text { concentrations } \\
\text { and high stocking } \\
\text { rates; potential for } \\
\text { escape and } \\
\text { competition with } \\
\text { native fish. }\end{array}$ \\
\hline
\end{tabular}




\begin{tabular}{|c|c|c|c|c|}
\hline $\begin{array}{l}\text { General Control } \\
\text { Approach }\end{array}$ & Method & Description & Reference & Comments \\
\hline & $\begin{array}{l}\text { Bio-Control: } \\
\text { Protozoa }\end{array}$ & Consume algae & $\begin{array}{l}\text { Mou et al. } \\
2013\end{array}$ & $\begin{array}{l}\text { Largely } \\
\text { experimental; } \\
\text { unknown } \\
\text { effectiveness and } \\
\text { impact to native } \\
\text { biota. }\end{array}$ \\
\hline & $\begin{array}{l}\text { Bio-Control: } \\
\text { Macrophytes/ } \\
\text { Algae }\end{array}$ & $\begin{array}{l}\text { Outcompete algae } \\
\text { for sunlight and } \\
\text { nutrients }\end{array}$ & & $\begin{array}{l}\text { Unknown } \\
\text { effectiveness in } \\
\text { large waterbodies; } \\
\text { uncertain impact } \\
\text { to desirable biota; } \\
\text { conflict with } \\
\text { navigation and } \\
\text { recreation }\end{array}$ \\
\hline & Copper & $\begin{array}{l}\mathrm{CuSO}_{4} \text { applied as } \\
\text { an algaecide }\end{array}$ & $\begin{array}{l}\text { Granquist } \\
2010\end{array}$ & $\begin{array}{l}\text { Copper can } \\
\text { accumulate in } \\
\text { sediments; } \\
\text { Impacts biota, and } \\
\text { not practical for } \\
\text { large scale } \\
\text { treatment. }\end{array}$ \\
\hline & $\begin{array}{l}\text { Hydrogen } \\
\text { peroxide }\end{array}$ & $\begin{array}{l}\text { Used to suppress } \\
\text { blooms }\end{array}$ & $\begin{array}{l}\text { Granquist } \\
2010\end{array}$ & $\begin{array}{l}\text { Not practical for } \\
\text { large-scale } \\
\text { treatment; } \\
\text { Impacts to biota } \\
\text { unknown. }\end{array}$ \\
\hline & Cavitation & $\begin{array}{l}\text { Breaks cells by } \\
\text { collapsing } \\
\text { vesicles }\end{array}$ & $\begin{array}{l}\text { Medina et } \\
\text { al. } 2016 a\end{array}$ & $\begin{array}{l}\text { High fields may } \\
\text { generate radicals, } \\
\text { which could } \\
\text { degrade toxins; } \\
\text { Localized effects. }\end{array}$ \\
\hline & $\begin{array}{l}\text { Ultrasonic } \\
\text { treatment }\end{array}$ & $\begin{array}{l}\text { Ultrasonic device } \\
\text { disrupts algal } \\
\text { cells }\end{array}$ & $\begin{array}{l}\text { Granquist } \\
2010\end{array}$ & $\begin{array}{l}\text { High fields may } \\
\text { generate radicals } \\
\text { which could } \\
\text { degrade toxins; } \\
\text { Localized effects. }\end{array}$ \\
\hline & $\begin{array}{l}\text { Isolation: } \\
\text { Perimeter } \\
\text { skirts }\end{array}$ & $\begin{array}{l}\text { Plastic or fabric } \\
\text { skirts suspended } \\
\text { in the water } \\
\text { column to contain } \\
\text { bloom }\end{array}$ & $\begin{array}{l}\text { Anderson } \\
2001\end{array}$ & $\begin{array}{l}\text { May not be } \\
\text { suitable for large } \\
\text { HAB events; May } \\
\text { conflict with } \\
\text { navigation and } \\
\text { recreation; } \\
\text { Unknown impacts } \\
\text { to biota. }\end{array}$ \\
\hline
\end{tabular}




\begin{tabular}{|c|c|c|c|c|}
\hline $\begin{array}{l}\text { General Control } \\
\text { Approach }\end{array}$ & Method & Description & Reference & Comments \\
\hline & Nutrient Traps & $\begin{array}{l}\text { Remove nutrients } \\
\text { with vegetated } \\
\text { riparian zones }\end{array}$ & $\begin{array}{l}\text { Medina et } \\
\text { al. } 2016 b\end{array}$ & $\begin{array}{l}\text { Effective if } \\
\text { capture of amount } \\
\text { is high compared } \\
\text { with total surface } \\
\text { water input. }\end{array}$ \\
\hline & $\begin{array}{l}\text { Sediment } \\
\text { Removal }\end{array}$ & $\begin{array}{l}\text { Dredged, nutrient } \\
\text { rich sediments to } \\
\text { remove potential } \\
\text { nutrient sources }\end{array}$ & Paerl 2014 & $\begin{array}{l}\text { Costly, can have } \\
\text { impacts to biota, } \\
\text { and not } \\
\text { appropriate for } \\
\text { areas still } \\
\text { receiving high } \\
\text { nutrient loads. }\end{array}$ \\
\hline & $\begin{array}{l}\text { Clay } \\
\text { Flocculants }\end{array}$ & $\begin{array}{l}\text { Dispersed clay } \\
\text { binds cells and } \\
\text { toxins }\end{array}$ & Kim 2012 & $\begin{array}{l}\text { Effective at } \\
\text { smaller scales; } \\
\text { impact to benthos } \\
\text { and length of } \\
\text { sequestration } \\
\text { unknown. }\end{array}$ \\
\hline $\begin{array}{l}\text { Watershed } \\
\text { Management }\end{array}$ & $\begin{array}{l}\text { Nutrient Source } \\
\text { Control }\end{array}$ & $\begin{array}{l}\text { Remove or } \\
\text { mediate nutrient } \\
\text { inputs }\end{array}$ & $\begin{array}{l}\text { Scavia et al. } \\
2016\end{array}$ & $\begin{array}{l}\text { USACE no } \\
\text { authority }\end{array}$ \\
\hline
\end{tabular}




\section{Operations Management Examples}

There are several case history reports of HAB management strategies and these are summarized in this section.

\subsection{Purrysburg Reservoir, SC}

The Purrysburg Reservoir is one of the more complete field studies described (Granquist et al. 2010). The Purrysburg Reservoir is managed by the Beaufort- Jasper Water and Sewer Authority in Okatie, SC. It is a shallow, approximately 65-acre reservoir supplied by the Savannah River and used by Okatie as a fresh water supply for the Purrysburg Water Treatment Plant. Several cyanobacterial bloom events lead to taste and odor issues (as opposed to toxin problems), which prompted the Authority to implement a control plan in 2008. The plan included water quality monitoring, ultrasonic units near the intake to the treatment plant, Grass carp, hydrogen peroxide treatment, manual algae removal, and opening a reservoir drain to increase the turnover (e.g., mixing of upper with lower water depths). These efforts were not successful in controlling the 2008 event; therefore, the reservoir was discontinued as a water source. The authors attributed this to a number of factors, with low turnover being the primary issue.

Anticipating similar problems in the future, the authors compared the Purrysburg Reservoir to the nearby Chelsea Reservoir, which was also managed by the same water Authority. The Chelsea reservoir had the same source water and similar depth, weather, and nutrient levels, but did not experience the same bloom issues. This was attributed to the higher turnover rate in this reservoir and higher turbidity, which may have limited algal growth.

A revised control plan combining physical, biological, and chemical processes was implemented in 2009. Perhaps the biggest difference was the use of a copper sulfate algaecide, along with hydrogen peroxide. Copper sulfate can have more long-term issues, but it also has a longer residual effect, which might explain why it made such a key difference. The Purrysburg Reservoir showed marked improvement. It could be used all year long, taste and odor complaints were reduced from 29 to 0 , and treatment of water by powder activated carbon, which previously was required, was not needed. 


\subsection{Lake Ketchum, WA}

Another case study of relevance is Lake Ketchum in Snohomish County, WA (Burghdoff 2012). Lake Ketchum is a 25-acre public lake, which makes other treatment options more feasible; however, it is of great interest because the HAB problems that occurred there were primarily from high phosphate loading due to agricultural runoff. While phosphate inputs into the lake have been reduced in recent years, the high levels of phosphate in the sediment continue to contribute to blooms.

Several strategies were considered for phosphate removal and/or reduction. Hypolimnetic withdrawal was considered to remove the phosphorous rich water from the bottom of the lake, but this approach was ultimately rejected because there was no supply of low phosphorus water to maintain the lake level (Burghdoff 2012). This strategy may be effective in reservoirs with higher inlet flow rates and those worth investigating for Corps managed reservoirs. Horizontal flushing was also considered. Horizontal flushing has been reported as playing a key role in controlling HABs (Paerl 2014). Horizontal flushing is the release of the upper layer of water (epilimion) from a reservoir. Horizontal flushing potentially decreases the residence time of the epilimion and is thought to decrease the suitableness of the waterbody for HABs, which benefit from long residence times. Limitations of this method are that the return water should be low in available nutrients (e.g., $\mathrm{P}$ and $\mathrm{N}$ ) as well as be available at the appropriate time. Another drawback may be the large amounts of HAB causing organisms transported downstream of reservoirs, which may lead to HAB events downstream of release (Graham et al. 2012). Aluminum sulfate treatment to bind and inactivate phosphorous in the lake was ultimately selected as the most cost effective approach to reduce phosphate; however, this is not likely to be cost effective on larger reservoirs.

\subsection{Jordan Lake, NC}

Jordan Lake, which is managed by USACE, is a reservoir in North Carolina that suffers from water quality issues related to algal blooms. To better manage water quality, a nutrient control program was developed that focuses on strict storm water management, wastewater discharge, and fertilizer management (NCDWQ 2014). In addition, $50 \mathrm{ft}$. wide riparian buffers are required on all surface waters that feed into the lake.

In addition, a study was conducted to assess the effectiveness of 36 SolarBee solar powered mixers (Futch 2014). If the initial tests were successful, 
then it was anticipated that 155 units would have been deployed on the lake. SolarBee has a website that presents chlorophyll data from April to October 2015 at several sites. Although the SolarBee treated area was lower in chlorophyll than that of a control area (Medora Corporation 2016), it was not significantly different (NCDWQ 2016) and the test program was discontinued (personal communication with Dana Matics, USACE Reservoir Manager). The application of these units was controversial such that environmental groups were concerned that the treatment, even if successful, could obscure the issue of nutrient control.

\subsection{Lake Wister, OK}

Flocculation and sedimentation of cyanobacteria works similarly to nutrient binding; however, using alum or other precipitants flocculate cells or toxins and allow them to settle and bind to the sediment (Patterson 2016). Successful examples include an application of polyaluminium chloride and a modified clay in Lake Rauwbraken (The Netherlands) (Lurling and van Oosterhout 2013) and at Lake Wister in LeFlore County in eastern Oklahoma in August of 2014. Lake Wister, a 100-acre cove where water intake is located, was treated with alum and sodium aluminate. Cyanobacteria were reduced by over $80 \%$ following treatment (Patterson 2015). The potential for treatment plant processes using flocculation will require removing cells through coagulation, flocculation, and filtration. Zamyadi et al. (2012) found breakthrough of cyanobacterial cells and cyanotoxins from final filtration; both accumulated in the sludge bed of clarifiers. Filter monitoring and maintenance is required when using such treatments while cell loads are high, which makes this process technical and laborious. Oxidants such as chlorine can deactivate toxins; however, chlorination of the treatment system can be effective as a detoxifying agent at lower toxin levels, but there are uncertainties about the quality of the treated water. Overall, this method for treatment of cells and toxins is expensive, technical, and may have a high environmental impact. 


\section{Concepts for Advanced Reservoir Treatment and Recommendations for Further Study}

\subsection{Reduce residence times}

Increasing the rate at which water flows through a reservoir may decrease optimal conditions needed for a HAB event and minimize potential impacts to lake ecosystem processes and biota that might occur with in situ treatment methods (e.g., algalcides). This HAB management activity can be undertaken by water control management at USACE controlled reservoirs. Research into this area can help determine the volume of water needed to move water through at a greater rate, timing of release, and strategies to minimize any impact to navigation and recreation. This management strategy is suitable for USACE managed reservoirs because USACE does not have a blanket authority to conduct projects solely for the benefit of water quality, but does have the authority to manage water levels in reservoirs for navigation, flood risk reduction, and recreation. However, some reservoirs are specifically authorized to manage for water quality in addition to other authorized uses. A pilot study of the application of this management method could be conducted in coordination between ERDC and USACE Districts (e.g., Louisville) that have frequent and somewhat predictable $\mathrm{HAB}$ events.

\subsection{Localized treatment}

One recurring theme of many of the treatment options is that while they are effective on a small scale, it is cost prohibitive to implement them on a large scale. However, it may be possible to use localized treatments, such as mixing, to target areas of a reservoir that are prone to bloom events. This would require increased sampling of the reservoir to pinpoint 'hot spots.' Access to quality, historic data would be beneficial to help identify areas of the reservoir that are most likely to experience a HAB. Likewise, treatments could be targeted to these areas, thus reducing the cost of treatment.

\subsection{Conclusions from study}

- There is a range of methods that can be applied to address HABs in reservoirs. 
- The efficacy of these methods decreases in larger reservoirs.

- None of the methods individually solves all problems or is applicable in all cases.

- In larger reservoirs, a combination of methods will likely be needed.

- There is a great need for dedicated and focused research in the area of reservoir water control and management of HABs. 


\section{References}

Anderson, D. M., P. Andersen, V. M. Bricelj, J.J. Cullen, and J. E. Rensel. 2001. Monitoring and management strategies for harmful algal blooms in coastal waters. APEC Report201-MR-01. Technical Series No. 59. Singapore, Asia: Asia Pacific Economic Program. Paris, France: Intergovernmental Oceanographic Commission of the United Nations Educational, Scientific and Cultural Organization (IOC/UNESCO).

Barrington, D. J., E. Reichwaldt, and A. Gharouani. 2013. The use of hydrogen peroxide to remove cyanobacteria and microcystins from waste stabilization ponds and hypereutrophic systems. Ecological Engineering 50: 86-94.

Beaver, J. R., E. E. Manis, K.A. Loftin, J. L. Graham, A. I. Pollard, and R. M. Mitchell. 2014. Land use patterns, ecoregion, and microcystin relationships in U.S. lakes and reservoirs: A preliminary evaluation. Harmful Algae 36: 57-62.

Burgdoff, M. and G. Williams. 2012. Lake Ketchum algae control plan. Everett, WA: Public Works Department, Snohomish County.

Chin, D. A. 2015. Identification of algae-nutrient relationships. The Open Hydrology Journal 9(1): 28-36.

Cong, H-B., T-L Huang, and B-B Chai. 2011. Research on applying a water-lifting aerator to inhibit the growth of algae in a source-water reservoir. International Journal of Environment and Pollution 45(1-3): 166-175.

Dortch, M. S. 1997. Water quality considerations in reservoir management. Journal of Contemporary Water Research and Education 108(1).

http://ucowr.org/files/Achieved_Journal_Issues/V108_A3Flood\%20Control\%2 oOperations.pdf

Fan, J., L. Ho, P. Hobson, and J. Brookes. 2013. Evaluating the effectiveness of copper sulphate, chlorine, potassium permanganate, hydrogen peroxide and ozone on cyanobacterial cell integrity. Water Research 47(14): 5153-5164.

Futch, M. 2014. Usefulness of SolarBee to improve Jordan Lake water debated. Fayetteville, NC: The Fayetteville Observer.

http://www.fayobserver.com/news/local/usefulness-of-solarbee-to-improvejordan-lake-water-debated/article_969340a7-b84b-5209-af7d41334ba9f74f.html

Granquist, V., C. Petry, B. Smith, and K. Sexton. 2010. Developing a reservoir algaecontrol plan for taste and odor prevention. Florida Water Resources Journal. http://www.bluetoad.com/display_article.php?id=541876

Graham, J. L., Ziegler, A. C., Loving, B. L., and K. A. Loftin, 2012. Fate and transport of Cyanobacteria and associated toxins and taste-and-odor compounds from upstream reservoir releases in the Kansas River, Kansas, September and October 2011. Scientific Investigations Report 2012-5129. Reston, Virginia: U.S. Department of the Interior, U.S. Geological Survey. 
Kim, H.-G. 2012. HAB mitigation strategies in Korea and eco-friendly new initiatives. In Proceedings, 15th International Conference on Harmful Algae (ICHA), 29 October - 2 November, Changwon, Korea, 219-222.

Krientz, L., P. K. Dadheech, J. Fastner, and K. Kotut. 2013. The rise of potentially toxin producing cyanobacteria in Lake Naivasha, Great African Rift Valley, Kenya. Harmful Algae 27: 42-51.

Kudela, R. M., E. Berdalet, S. Bernard, M. Burford, L. Fernand, S. Lu, S. Roy, P. Tester, G. Usup, R. Magnien, D. M. Anderson, A. Cembella, M. Chinain, G. Hallegraeff, B. Reguera, A. Zingone, H. Enevoldsen, and E. Urban. 2015. Harmful algal blooms: A scientific summary for policy makers. IOC/INF-1320. Paris, France: (IOC/UNESCO).

Li, P., Y. Song, and S. Yu. 2013. Removal of Microcystis aeruginosa using hydrodynamic cavitation: Performance and mechanisms. Water Research 62: 241-248.

Li, P., Y. Song, S. Yu, and H-D Park. 2015. The effect of hydrodynamic cavitation of Microcystis aeruginosa: Physical and chemical factors. Chemosphere 136: 245251.

Lurling, M. and F. van Oosterhout. 2013. Controlling eutrophication by combined bloom precipitation and sediment phosphorus inactivation. Water Research 47(17): 6527-6537.

Matics, D., (USACE Reservoir Manager). 2016. Personal communication.

Medina, V. F., C. S. Griggs, and C. Thomas. 2016a. Evaluation of the destruction of the harmful cyanobacteria, Microcystis aeruginosa, with a cavitation and superoxide generating water treatment reactor. Bulletin of Environmental Toxicology and Contamination 96(6): 791-796. DOI: 10:1007/Soo128-016-1742-6.

Medina, V. F., R. Fischer, and C. Ruiz. 2016b. Riparian Buffers for Runoff Control and Sensitive Species Habitat on U.S. Army Corps of Engineers Lake and Reservoir Projects. ERDC WQTN-16-1. Vicksburg, MS: U.S. Army Engineer Research and Development Center.

Medora Corporation. 2016. Jordan Lake Demonstration Project: 2014-2016. (http://lakes.medoraco.com/jordan-lake-data

Michalak, A. M. E. J. Anderson, S. Boland, N. S. Bosch, T. B. Bridgeman, J. D. Chaffin, K. Cho, R. Confesor, I. Daloglu, J. V. DePinto, M. A. Evans, G. L. Fahnenstiel, L. He, J. C. Ho, L. Jenkins, T. H. Johengen, K. C. Kuo, E. LaPorte, X. Liu, M. R. McWilliams, M. R. Moore, D. J. Posselt, R. P. Richards, D. Scavia, A. L. Steiner, E. Verhamme, D. M. Wright, and M. A. Zagorski. 2013. Record-setting algal bloom in Lake Erie caused by agricultural and meteorological trends consistent with expected future trends. Proceedings of the National Academy of Sciences 110(16): 6448-6452.

Mou, X., Lu, X., Jacob, J., Sun, S. and R. Heath. 2013. Metagenomic identification of bacterioplankton taxa and pathways involved in microcystin degradation in Lake Erie. PLoS ONE 8(4): eoo61890. doi:10.1371/journal.pone.0061890 
Mur, L. R., O. M. Skulberg, and H. Utkilen. 1999. Cyanobacteria in the Environment. In Toxic cyanobacteria in water: A guide to their public health consequences, monitoring, and management, ed., I. Chorus and J. Bartram, Chapter 2. London, England: E and FN Spon.

National Science and Technology Council. 2016. Harmful algal blooms and hypoxia comprehensive research plan and action strategy: An interagency report. Washington, DC: Executive Office of the President.

North Carolina Department of Water Quality (NCDWQ). 2014. Jordon Lake nutrient management strategy.

http://portal.ncdenr.org/c/document_library/get_file?uuid=fd6c684b-2c8e4617-a890-551ad77cd68o\&groupId=235275

North Carolina Department of Water Quality (NCDWQ). 2016. Survey of in situ strategies for mitigation of water quality impairments in North Carolina. Raleigh, NC: North Carolina Department of Environmental Quality, Division of Water Resources.

Oberholster, P. (Research Biologist, Center for Scientific and Industrial Research, Pretoria, South Africa). 2016. Personal Communication.

Paerl, H. W. 2014. Mitigating harmful cyanobacterial blooms in a human- and climatically-impacted world. Life 4(4): 988-1012.

Patterson, S. 2015. The Quarry Island Cove nutrient inactivation project. In Proceedings, Oklahoma Clean Lakes and Watersheds Association Conference, 9 April, Stillwater, OK.

Patterson, S. D. 2016. Assessing and mitigating source water cyanotoxin vulnerability. http://www.swawwa.org/ace16presentations/Assessing_\&_Mitigating_Source_ Water_Cyanotoxin_Vulnerability---Steven_Patterson.pdf

Roelke, D. L., B. W. Brooks, J. P. Grover, D. M. Kalisek, and B. L. Harris. 2012. Approaches to golden algal control: In-Lake Mesocosm experiments. ERDC/EL CR-12-1. Vicksburg, MS: U.S. Army Engineer Research and Development Center.

Scavia, D. M. Kalcic, R. L. Muenich, N Aloysius, C. Boles, R. Confesor, J. DePinto, M. Gildow, J. Martin, J. Read, T. Redder, S. Sowa, Y.-C. Wang, and H. Yen. 2016. Informing Lake Erie agriculture nutrient management via scenario evaluation. Ann Arbor, MI: University of Michigan.

Shephard, G. S., S. Stockenstrom, D. De Villiers, W. J. Engelbrecht, E. W. Sydenham, and G. F. S. Wessels. 1998. Photocatalytic degradation of cyanobacterial microcystin toxins in water. Toxicon 36(12): 1895-1901.

Sindelar, H. R., J. N. Yap, T. H. Boyer, and M. T. Brown. 2015. Algae scrubbers for phosphorus removal in impaired waters. Ecological Engineering 85: 144-158.

Schneider, M. L., S. C. Wilhelms, and L. I. Yates. 2004. SELECT version 1.o beta: A onedimensional reservoir selective withdrawal model spreadsheet. ERDC/EL SR04-01. Vicksburg, MS: U.S. Army Engineer Research and Development Center. 
U.S. Army Corps of Engineers 2008. Pre-Reconnaissance report for the Wister Lake Ecosystem Restoration Project. Contract No. W912BV-07-D-2005, Task Order 0002. Tulsa, OK: U.S. Army Corps of Engineers, Tulsa District.

Wikipedia. 2011. Algal blooms. https://en.wikipedia.org/wiki/Algal_bloom

Williams, A. 2015. Los Angeles rolls out a shady solution to the drought problem. Water \& Wastewater International 30(5).

http://www.waterworld.com/articles/wwi/print/volume-30/issue-5/regionalspotlight/los-angeles-rolls-out-a-shady-solution-to-the-drought-problem.html

Wu, Z., H. Shen, B. Ondruschka, Y. Zhang, W. Wang, and D. H. Bremner. 2012. Removal of blue-green algae using the hybrid method of hydrodynamic cavitation and ozonation. Journal of Hazardous Materials 235-236: 152-158.

Xie, P., and J. Liu. 2001. Practical success of biomanipulation using filter-feeding fish to control cyanobacteria blooms: A synthesis of decades of research and application in a subtropical hypereutrophic lake. Scientific World 1: 337-356.

Zamyadi, A., S. L. MacLeod, Y. Fan, N. McQuaid, S. Dorner, S. Sauve, and M. Prevost. 2012. Toxic cyanobacterial breakthrough and accumulation in a drinking water plant: A monitoring and treatment challenge. Water Research 46(5): 1511-1523. 


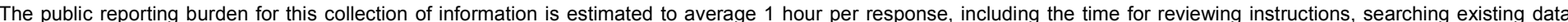



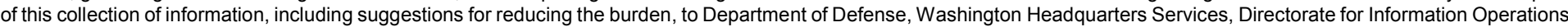


law, no person shall be subject to any penalty for failing to comply with a collection of information if it does not display a currently valid OMB control number.

PLEASE DO NOT RETURN YOUR FORM TO THE ABOVE ADDRESS.

\begin{tabular}{c|l|l}
\hline $\begin{array}{c}\text { 1. REPORT DATE } \\
\text { July } 2017\end{array}$ & $\begin{array}{l}\text { 2. REPORT TYPE } \\
\text { Final Technical Report }\end{array}$ & 3. DATES COVERED (From - To) \\
May 2016 - March 2017
\end{tabular}

\section{TITLE AND SUBTITLE}

Review and Evaluation of Reservoir Management Strategies for Harmful

Algal Blooms

5a. CONTRACT NUMBER

5b. GRANT NUMBER

5c. PROGRAM ELEMENT NUMBER

5d. PROJECT NUMBER

WOTS-16-014

Brook D. Herman, Jed O. Eberly, Carina M. Jung, and

Victor F. Medina 5e. TASK NUMBER

5f. WORK UNIT NUMBER

8. PERFORMING ORGANIZATION REPORT NUMBER

ERDC/EL TR-17- 11

10. SPONSOR/MONITOR'S ACRONYM(S)

USACE

11. SPONSOR/MONITOR'S REPORT NUMBER(S)

12. DISTRIBUTION/AVAILABILITY STATEMENT

Approved for public release; distribution is unlimited.

\section{SUPPLEMENTARY NOTES}

\section{ABSTRACT}

The purpose of this report is to review and evaluate available information regarding reservoir operation strategies for management of harmful algal blooms (HABs). HABs can be problematic, creating eutrophication and taste and odor issues. HABs also involve the release of toxins in the water column, which can cause sickness by ingestion and skin contact. This report presents the results of a review of journal articles, reports, published accounts of potential management options, effectiveness of management, and potential impacts of management actions on lake/reservoir ecosystem processes and biota, and recommendations for future research. This report concluded that there is a range of methods that can be applied to address HABs in reservoirs. The efficacy of these methods decreases in larger reservoirs. No one method individually solves all problems or is applicable in all cases, a combination of methods will likely be needed. More research is needed to effectively control and prevent HABs.

\section{SUBJECT TERMS}

Harmful algal blooms, Water quality, Navigation pools, Reservoir operations

\begin{tabular}{|c|c|c|c|c|c|}
\hline \multicolumn{3}{|c|}{ 16. SECURITY CLASSIFICATION OF: } & \multirow{3}{*}{$\begin{array}{l}\text { 17. LIMITATION OF } \\
\text { ABSTRACT } \\
\text { UU }\end{array}$} & \multirow{3}{*}{$\begin{array}{l}\text { 18. NUMBER OF } \\
\text { PAGES } \\
30\end{array}$} & \multirow{2}{*}{$\begin{array}{l}\text { 19a. NAME OF RESPONSIBLE PERSON } \\
\text { Brook Herman }\end{array}$} \\
\hline a. REPORT & b. ABSTRACT & c. THIS PAGE & & & \\
\hline 0 & & & & & 19b. TELEPHONE NUMBER (Include area code) \\
\hline
\end{tabular}

